\section{The Use of Surgical Drains amongst the Orthopaedic Surgeons of Kuwait}

\section{Bader Al-Hindi', Aliaa Khaja ${ }^{1 *}$, Sager S Hanna ${ }^{1}$, Mohammad Alfeeli', Mohammad AIAwadh' ${ }^{1}$ and Ali Jarragh ${ }^{2}$}

${ }^{1}$ Department of Trauma and orthopedics, Al Razi Orthopedic Hospital, Kuwait City, Kuwait

${ }^{2}$ Deprtment of Medicine, Kuwait University, Jaber Hospital, Khalid Ben Abdul Aziz Street, Kuwait

\begin{abstract}
Background: The use of surgical drains has been a controversial topic among all surgical specialties and the outcome of its use has conflicting data especially in orthopaedic surgery. The aim of this study was to see if orthopaedic surgeons in Kuwait know the current guidelines and evidence-based practice. The study also aimed to investigate if demography, background, experience as well as subspecialty among orthopaedic surgeons can influence their usage of surgical drains. In addition, to assess their adherence to the international recommendations for the use of surgical drains.
\end{abstract}

Method: An electronic survey was constructed, based on the current evidence from the literature provided by high-level institutions/organizations and Evidence-Based Medicine (EBM) sources. Including evidence from the $\mathrm{WHO}, \mathrm{CDC}$ and Cochrane reviews. The survey was sent to all orthopedic surgeons in Kuwait (Total of 116), 73 participants responded (63\% response rate). In addition the questions also surveyed demographic data regarding subspecialty and technical habits of use.

Results: The survey included a total of 73 orthopedic surgeons from different hospitals and subspecialties .It contained a total of 21 questions in which 7 questions were further subdivided into 6 categories. The categories represent 6 items of the current EBM policies, aiming to address the participant's knowledge by point scoring. A total score

*Corresponding author: Aliaa Khaja, Department of Trauma and orthopedics, Al Razi Orthopedic Hospital, Kuwait City, Kuwait, Tel: +965 66135777; E-mail: aliaa.khaja@gmail.com

Citation: Al-Hindi B, Khaja A, Hanna SS, Alfeeli M, AlAwadh M, et al. (2020) The Use of Surgical Drains amongst the Orthopaedic Surgeons of Kuwait. Surg Curr Trend Innov 4: 036.

Received: May 18, 2020; Accepted: May 23, 2020; Published: May 30, 2020

Copyright: (c) 2020 Al-Hindi B, et al. This is an open-access article distributed under the terms of the Creative Commons Attribution License, which permits unrestricted use, distribution, and reproduction in any medium, provided the original author and source are credited. of 6 (maximum score) is only achieved by 1 surgeon. 4 Surgeons had a score of 0 . The majority of surgeons $(88 \%)$ scored between 1 and 3 points out of 6 . All the secondary objectives were statistically insignificant.

Conclusion: These results show that orthopedic surgeons in Kuwait are not updated with the current evidence-based practice regarding the use of surgical drains in Orthopedic Surgery.

Keywords: Infection; Orthopedic surgery; Surgical drains

\section{Introduction}

The use of surgical drains was historically recorded by Hippocrates in 460-370 BC; he had used hollow tubes to drain an empyema in the abdomen. However, the surgeon who was firstly accredited with the use of modern surgical drains among orthopedic patients was Ambroise Pare 1510-1590 [1,2].

The use of orthopedic surgical drains has been subject to controversy [3]. On one hand, it is a tool used for evacualting surgical site hematomas, preventing the formation of a cultural medium for infection $[3,4]$. Infections are a much dreaded complication most surgeons face, and are the management is usually complex [5]. Another complication orthopedic surgeon's fear is compartment syndrome [6]. So they believe drains help reduce the risk of this detrimental emergency $[5,6]$. On the other hand, the literature also reports that retrograde infection might be introduced. In other words, what comes out can get in. This was seen in old draining systems $[7,8]$. Yet there is still a considerable risk of this happening when utilizing newer drainage systems [8].

While some orthopedic subspecialties, for instance in spine surgery, prefer the drains, others [7-9]. Others like reconstruction surgery avoid it, for fear of biofilm formation. The results of infections could at times be catastrophic $[8,10]$.

Although there are exceptions, many schools of thought have provided guidelines and protocols for using surgical drains [11]. The most commonly used examples are the National Institute for Health and Care Excellence, and the WHO guidelines for SSI [11,12]. For the purpose of this study we will be using the latter, as it is used as a reference for the surgical drains policy in Kuwaiti Hospitals. The guideline provides details on prophylactic antibiotic use, and time of drain removal timings recommended to reduce the risks of surgical site infections.

The current literature, however, favors moving away from the use of drains and supports trends that minimizes the complications of using this utility when possible [12]. The usage of surgical drains has often led to increased numbers of days spent in hospital post-operatively and number of wound dressings [13]. This would ultimately decrease the cost-effectiveness of healthcare facilities, and inversely affect patient satisfaction rates [13-15]. Another vital issues reported in the literature is the increased need for blood transfusions in patients 
Citation: Al-Hindi B, Khaja A, Hanna SS, Alfeeli M, AlAwadh M, et al. (2020) The Use of Surgical Drains amongst the Orthopaedic Surgeons of Kuwait. J Surg Curr Trend Innov 4: 036.

who have surgical drains inserted [14,15]. Blood transfusions open the door for unnecessary transfusion related complications and an increase demand for blood that could be utilized elsewhere, especially since it is already a scarce resource. Alternatives to avoid these blood transfusions related issues have been proposed, and the evidence is promising $[14,15]$. To the author's current knowledge, no studies have been previously done to assess the knowledge of orthopedic surgeons regarding the use of surgical drains.

The aim of this study is to identify possible knowledge deficiencies and try to address them. This in turn will improve the current clinical practice. The need for this study is to scan for misconceptions and old practices that our participants still believe to be true, like the risks of infection hematomas, wound dehiscence, and the need for secondary surgery. It is important for our surgeons to know the consequences of malpractice and not keeping their knowledge up-to-date with the current guidelines.

\section{Methodology}

In this study, a descriptive approach was followed to quantitatively measure the level of knowledge of participants about the surgical drains and to establish their technical habits when using the drains.

For this purpose, seven multiple choice questions were included in the survey construct of 21 questions. A total of 7 questions with only one correct answer per question were designed to assess current EBM facts into 6 categories; Hematoma, Seroma and Wound Dehiscence, Blood transfusion, need for secondary surgery, wound infection, wound dressing and length of hospital stay. A point scoring system was used to calculate the surgeons' level of knowledge about surgical drain use. The lowest score was zero and the highest score was six. The scores are also converted into a percentage value for easier analytical perception.

The survey itself was distributed via electronic communication; all 116 targeted participants received the survey 2 times, with a two week interval. Only 73 participants responded (Response rate 63\%).

The data analysis was done using SPSS IBM (v. 26) and Graphpad Prism (v. 8). Mann-Whitney U test and Kruskal-Wallis $\mathrm{H}$ test are performed to compare the level of knowledge of different demographic groups about the surgical drains, and their routine application among the physicians. The survey being factual based, using yes or no responses, construct validity and reliability of this questionnaire was not necessary.

\section{Results}

In table 1, the demographic characteristics of the individuals who participated in this study are shown. The absolute majority of the participants were male $(\mathrm{N}=71)$, and only 2 participants were female $(2.7 \%)$.

Around $60 \%$ of all participants were working in Al-Razi Orthopaedic Hospital, while $23 \%$ of them were employed in Al-Farwaniya Hospital. The majority of the participants (64.4\%) were between 35 to 44 years old, while $22 \%$ of them were older than 45 years old, and the rest were between 22 and 34 years old. In addition, it was shown that around $66 \%$ of all participants who worked at the hospitals were Registrars, while around 13\% were Specialist or Senior Specialists.

\begin{tabular}{|c|c|c|c|c|}
\hline & Frequency & Percentage & Mean (\%) & Median (\%) \\
\hline \multicolumn{3}{|c|}{ Gender } & & \\
\hline Female & 2 & 2.7 & & \\
\hline Male & 71 & 97.3 & & \\
\hline \multicolumn{3}{|c|}{ Hospital } & $H(5)=2.142$ & $\mathrm{p}=0.829$ \\
\hline Al-Adan Hospital & 2 & 2.7 & $28.60 \%$ & $28.60 \%$ \\
\hline Al-Farwaniya Hospital & 17 & 23.3 & $28.60 \%$ & $28.60 \%$ \\
\hline Al-Jahra Hospital & 2 & 2.7 & $28.60 \%$ & $28.60 \%$ \\
\hline $\begin{array}{c}\text { Al-Razi Orthopedic } \\
\text { Hospital }\end{array}$ & 44 & 60.3 & $26.30 \%$ & $28.60 \%$ \\
\hline Military Hospital & 1 & 1.4 & $14.30 \%$ & $14.30 \%$ \\
\hline $\begin{array}{c}\text { Mubarak Al-Kabeer } \\
\text { Hospital }\end{array}$ & 7 & 9.6 & $30.60 \%$ & $28.60 \%$ \\
\hline \multicolumn{3}{|c|}{ Age Group } & $\mathrm{H}(3)=2.207$ & $\mathrm{p}=0.531$ \\
\hline $22-34$ & 10 & 13.7 & $32.90 \%$ & $28.60 \%$ \\
\hline $35-44$ & 47 & 64.4 & $27.40 \%$ & $28.60 \%$ \\
\hline $45-54$ & 10 & 13.7 & $21.40 \%$ & $14.30 \%$ \\
\hline $55-64$ & 6 & 8.2 & $26.20 \%$ & $21.40 \%$ \\
\hline \multicolumn{3}{|c|}{ Job Title } & $H(5)=4.608$ & $\mathrm{p}=0.466$ \\
\hline Assistant Registrar & 5 & 6.8 & $37.10 \%$ & $42.90 \%$ \\
\hline Consultant & 3 & 4.1 & $23.80 \%$ & $14.30 \%$ \\
\hline Registrar & 48 & 65.8 & $26.20 \%$ & $28.60 \%$ \\
\hline Senior Registrar & 7 & 9.6 & $30.60 \%$ & $28.60 \%$ \\
\hline Senior specialist & 2 & 2.7 & $21.40 \%$ & $21.40 \%$ \\
\hline Specialist & 8 & 11 & $26.80 \%$ & $28.60 \%$ \\
\hline \multicolumn{3}{|c|}{ Speciality Field } & & \\
\hline Spine & 6 & 8.2 & & \\
\hline Hand & 7 & 9.6 & & \\
\hline Arthroscopy & 7 & 9.6 & & \\
\hline Arthroplasty & 19 & 26 & & \\
\hline Lower Limb Deformity & 4 & 5.5 & & \\
\hline Upper Limb deformity & 3 & 4.1 & & \\
\hline Foot and Ankle & 11 & 15.1 & & \\
\hline Upper Limb Trauma & 43 & 58.9 & & \\
\hline Lower Limb Trauma & 45 & 61.6 & & \\
\hline Pelvis & 12 & 16.4 & & \\
\hline Paediatric Orthopedics & 15 & 20.5 & & \\
\hline Oncology & 1 & 1.4 & & \\
\hline
\end{tabular}

Table 1: Demographic Characteristics of the participants - Mean and median total score $(\%)$ of the seven guideline questions are also calculated for each grouping along with Kruskall-Wallis $\mathrm{H}$ test to determine differences between different demographic groups; the results are reported as $\mathrm{H}$ (df) and $\mathrm{p}$ value.

Furthermore, it could be described that the most common subspecialty among the participants were Upper (61.6\%) and Lower (59\%) Limb Trauma with Arthroplasty (26\%) at third place.

When it comes to the level of knowledge about the surgical drains, the mean and median of total score were calculated. The mean was $1.904( \pm 1.082)$ while the median was 2 . The maximum observed score (6) obtained only by one participant, and the lowest grade (0), was scored by 4 participants. Around $88 \%$ of all participants reached a total score between one and three. According to the Kruskall-Wallis $\mathrm{H}$ test which was performed to determine total score differences between various demographic groups, no significant difference could 
Citation: Al-Hindi B, Khaja A, Hanna SS, Alfeeli M, AlAwadh M, et al. (2020) The Use of Surgical Drains amongst the Orthopaedic Surgeons of Kuwait. J Surg Curr Trend Innov 4: 036.

be established between different groupings in the level of knowledge about the surgical drains $(p>0.05)$. In table 2 , the total score is broken down into the 7 questions, and the frequency of correct and wrong responses for each question is calculated.

\begin{tabular}{|c|c|c|c|c|}
\hline \multirow{2}{*}{$\begin{array}{c}\text { General Guidelines about Surgical } \\
\text { Drains }\end{array}$} & \multicolumn{2}{|c|}{ Correct } & \multicolumn{2}{c|}{ Wrong } \\
\cline { 2 - 5 } & Frequency & $\%$ & Frequency & $\%$ \\
\hline $\begin{array}{c}\text { Do you think drains increase or de- } \\
\text { crease the risk of haematoma/seromas } \\
\text { or wound dehiscence? }\end{array}$ & 10 & $13.70 \%$ & 63 & $86.30 \%$ \\
\hline $\begin{array}{c}\text { Does the usage of drains increase or } \\
\text { decrease the need for transfusions? }\end{array}$ & 10 & $13.70 \%$ & 63 & $86.30 \%$ \\
\hline $\begin{array}{c}\text { Do you think drains increase or de- } \\
\text { crease the requirements for secondary } \\
\text { surgery? }\end{array}$ & 30 & $41.10 \%$ & 43 & $58.90 \%$ \\
\hline $\begin{array}{c}\text { Do you think drains increase or de- } \\
\text { crease the risk of wound infections? }\end{array}$ & 11 & $15.10 \%$ & 62 & $84.90 \%$ \\
\hline $\begin{array}{c}\text { Does removing the drain before } 5 \text { days } \\
\text { post-op decrease the risk of infection? }\end{array}$ & 11 & $15.10 \%$ & 62 & $84.90 \%$ \\
\hline $\begin{array}{c}\text { Do you think drains increase or } \\
\text { decrease the requirement for wound } \\
\text { dressings? }\end{array}$ & 32 & $43.80 \%$ & 41 & $56.20 \%$ \\
\hline $\begin{array}{c}\text { Do you think drains increase or } \\
\text { decrease the requirement for stay in } \\
\text { hospital? }\end{array}$ & 35 & $47.90 \%$ & 38 & $52.10 \%$ \\
\hline TOTAL & $\mathbf{2 7 . 2 0 \%}$ & & $\mathbf{7 2 . 8 0 \%}$ \\
\hline
\end{tabular}

Table 2: General Guideline questions about using surgical drains - the questions are multiple choices and only one is correct. The percentages of correct and wrong answers for each question are illustrated in this table.

\section{The relationship between experience and level of knowl- edge about surgical drains}

In order to measure the level of association between experience in the orthopaedic field and the level of knowledge about the evidence-based practice of surgical drains, the Spearman correlation coefficient calculated was $-0.278(\mathrm{p}<0.001)$. Unfortunately, the results showed a negative correlation between the level of theoretical knowledge about the surgical drains and experience of the participants in orthopaedic field.

\section{Habits \& complications using surgical drains}

As shown in Figure 1, it is indicated that $54.8 \%$ of all participants use surgical drains frequently, while $5.5 \%$ always use drains during surgery. Forty Eight percent of all participants reported that drains rarely cause unnecessarily prolonged hospital stay, while $28.8 \%$ reported occasional prolongation.

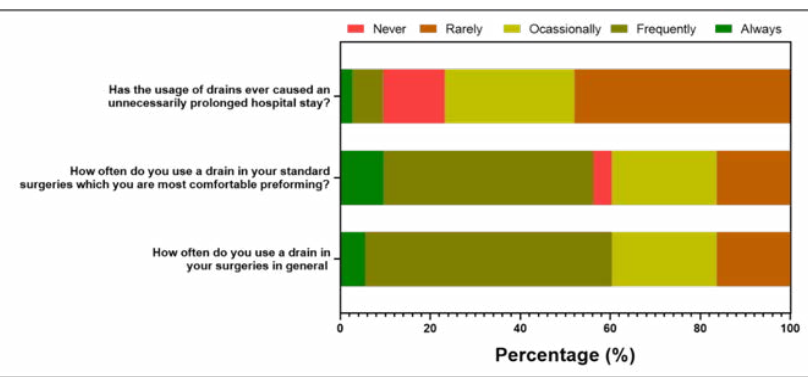

Figure 1: Percentages of habits \& complications using surgical drains.

\section{Technical habits of using drains}

According to the results of the survey (Table 3), 51\% of all participants use closed drain systems, while only $2.8 \%$ of them use open drain systems. Multilayer drains were used by $30.1 \%$ of the participants. In addition, the most common drain size which was used in surgeries was Medium size drain (61.6\%). Large drains were used by $28.8 \%$ of the participants. Seventy four percent used only one drain for the same location. The majority $(75.3 \%)$ reported that they use different incisions to insert the drain, while $24.7 \%$ use the same incision. With regards to the location of the drain, the answers of the participants were quite heterogenous. The drain was inserted below the incision in $43.8 \%$ of the time, while $27.4 \%$ placed the drain above the incision, and $28.8 \%$ parallel to it. However, approximately all of the participants $(91.8 \%)$ indicated to secure the drain with suture. When it comes to using antibiotics, $67.1 \%$ of the participants unnecessary to specifically use prophylaxis for drain usage. Second (52.1\%) or the third (38.4\%) post-operative day are reported by participants to be the most common time to remove the drain. After removal of the drain, the patients are normally discharged within the same day $(28.8 \%)$ or most commonly after 24 hours (53.4\%).

\section{Discussion}

This survey study looked into the current practice of using surgical drains in orthopaedic surgery in Kuwait, and what the current evidence regarding this topic suggests, compared to whether the surgeons in Kuwait are adherent to it. The main 6 categories that we used to compare benefit vs no benefit differences were:

\section{Hematoma, seroma and wound dehiscence (no difference)}

A retrospective study by the Journal of Neurosurgery: Spine $(n=1799)$ found no statistical significance with regards to Hematomas, Seromas and wound Dehiscence $[11,16]$. The most current studies were done by breast surgeons post-mastectomy. Their conclusion is reflected in the WHO guidelines and A Cochrane review [17]. It is worth noting that the participants of the previous studies had a higher risk of bruising. This in turn resulted in a large number of surgeons refraining from using surgical drains altogether in their practice $[18,19]$.

\section{Blood transfusion (increase)}

The orthopaedic literature has a long history of inquisitive research regarding the use of postoperative surgical site drains $[16,20]$. For instance, in total joint arthroplasty and some spinal surgeries, surgical site drains were associated with increased rates of transfusion [11-13]. These results are supported by a Cochrane review [20-22]. Of our study cohort, an alarming $86 \%$ of them did not know this.

\section{Secondary surgery (no difference)}

Both the Journal of Neurosurgery: Spine and Cochrane review analysis both confirmed that not using a surgical drain didn't increase the odd of a secondary surgery or return to the theatre [17-20]. Yet about $60 \%$ of our participants thought the contrary.

\section{Wound infection(no difference)}

A large percentage of our participants believed that drains reduce the risk of infection. Yet, all hospital policies enforce a minimum of 3 doses of prophylactic antibiotic rule for all surgeries in Kuwait, despite evidence showing that 1 prophylactic dose is enough. 
Citation: Al-Hindi B, Khaja A, Hanna SS, Alfeeli M, AlAwadh M, et al. (2020) The Use of Surgical Drains amongst the Orthopaedic Surgeons of Kuwait. J Surg Curr Trend Innov 4: 036.

- Page 4 of 6 •

There are no clear guidelines for antibiotic use when patients have surgical drains inserted. This is why educating our surgeons on evidence is necessary, since most surgeons practice based on their acquired experience and not EBM.

\begin{tabular}{|c|c|c|}
\hline & Frequency & Percentage \\
\hline \multicolumn{3}{|c|}{ How often do you use a drain in your surgeries in general? } \\
\hline Always & 4 & 5.5 \\
\hline Frequently & 40 & 54.8 \\
\hline Occasionally & 17 & 23.3 \\
\hline Rarely & 12 & 16.4 \\
\hline \multicolumn{3}{|c|}{$\begin{array}{l}\text { How often do you use a drain in your standard surgeries which you are most com- } \\
\text { fortable preforming? }\end{array}$} \\
\hline Always & 7 & 9.6 \\
\hline Frequently & 34 & 46.6 \\
\hline Never & 3 & 4.1 \\
\hline Occasionally & 17 & 23.3 \\
\hline Rarely & 12 & 16.4 \\
\hline \multicolumn{3}{|c|}{ What type of drain system do you use? } \\
\hline Active drain systems & 12 & 16.4 \\
\hline Closed drain systems & 37 & 50.7 \\
\hline Closed drain systems; Active drain systems & 9 & 12.3 \\
\hline Closed drain systems; Passive drain systems & 1 & 1.4 \\
\hline $\begin{array}{l}\text { Open drain systems; Closed drain systems; corrugated } \\
\text { drains }\end{array}$ & 1 & 1.4 \\
\hline $\begin{array}{l}\text { Open drain systems; Closed drain systems; Passive drain } \\
\text { systems; corrugated drains }\end{array}$ & 1 & 1.4 \\
\hline Passive drain systems & 12 & 16.4 \\
\hline \multicolumn{3}{|c|}{ What size drain do you usually use? } \\
\hline Large & 21 & 28.8 \\
\hline Medium & 45 & 61.6 \\
\hline Small & 7 & 9.6 \\
\hline \multicolumn{3}{|l|}{ Where do you place the drain? } \\
\hline Above the incision & 20 & 27.4 \\
\hline Below the incision & 32 & 43.8 \\
\hline Parallel to the incision & 21 & 28.8 \\
\hline \multicolumn{3}{|c|}{ On average, by which post-operative day do you remove the drain? } \\
\hline Day 1 & 1 & 1.4 \\
\hline Day 2 & 38 & 52.1 \\
\hline Day 3 & 28 & 38.4 \\
\hline Day 4 & 3 & 4.1 \\
\hline Day 5 & 3 & 4.1 \\
\hline \multicolumn{3}{|c|}{ How soon after the removal of the drain do you discharge your patient? } \\
\hline After 24 hours & 39 & 53.4 \\
\hline After 48 hours & 10 & 13.7 \\
\hline More than 48 hours & 3 & 4.1 \\
\hline Same day & 21 & 28.8 \\
\hline \multicolumn{3}{|c|}{ Has the usage of drains ever caused an unnecessarily prolonged hospital stay? } \\
\hline Almost always & 2 & 2.7 \\
\hline Frequently & 5 & 6.8 \\
\hline Never & 10 & 13.7 \\
\hline Occasionally & 21 & 28.8 \\
\hline Rarely & 35 & 47.9 \\
\hline \multicolumn{3}{|c|}{ Do you think drains increase or decrease the risk of prosthetic infections? } \\
\hline Decrease & 17 & 23.3 \\
\hline Increase & 15 & 20.5 \\
\hline
\end{tabular}

\begin{tabular}{|c|c|c|}
\hline No effect & 18 & 24.7 \\
\hline Not sure & 23 & 31.5 \\
\hline
\end{tabular}

Table 3: Technical habits and opinions about the usage of surgical drains.

The WHO SSI guidelines produced a pooled analysis. This analysis showed that there is insufficient evidence to ascertain if prolonged antimicrobial prophylaxis is either beneficial or harmful SSI $[11,22]$. However,the current recommendations advocate against the use of prophylactic antibiotics in patients beyond 24 hours [11]. As this will cause and increase in the rate of Clostridium Difficile infections and acute kidney injuries. It has also been established that there is insufficient evidence that the date of drain removal does statistically increase of decrease the risk of SSI [11].

The Cochrane review and the Journal of Neurosurgery: Spine both published and they both concluded that there was no difference in infection rate among patients who had a surgical drain when compared to patients who didn't $[11,19,20]$. The Cochrane review further declared that the correlation between wound healing and drain usage was statistically insignificant $[11,23]$.

\section{Wound dressing (increase)}

The majority of the studies reached a consensus that the requirement for regular dressing was increased among patients with surgical drains more than 2-folds, but this didn't attribute to neither an increase nor decrease in the surgical site infection risk [11,15,24]. Although our study did not aim to measure the frequency of dressing exchange, about $40 \%$ of the participants in this study had knowledge of this.

\section{Length of hospital stay(increase)}

Opposing evidence was available from the WHO SSI guidelines and a Cochrane review. WHO used an non-orthopaedic metanalysis and suggested an increase in hospital stay [11,14-16]. The evidence from Cochrane review was based on 5 orthopaedic studies that were small in number and weak in design $[11,15,25]$. There is however, no current evidence that states otherwise. The vast bulk (approximately $50 \%$ ) of our participants were aware of this fact and have witnessed this increased length of hospital stay in their practice.

In brief, the orthopaedic surgeon should justify its use as per Guideline Development Group (GDG). Their survey acknowledged in their survey that drains are painful and uncomfortable to patients and patients wish them taken our early. Even for patients who developed seromas that required a return to the hospital and aspiration $[7,25,26]$.

\section{Conclusion}

The approach to the use of surgical drainage systems is not a "one size fit all," and it should be on a case by case manner. However, there is a deficiency of knowledge amongst the Kuwaiti Orthopaedic surgeons that merit for defensive medicine and probable malpractice. Orthopaedic surgeons in Kuwait should adhere with the current evidence-based approach to the usage of surgical drains.

\section{Limitations}

The small number of participants reflected on the accuracy of the data; however the response rate was relatively higher than expected. Volume $4 \cdot$ Issue $2 \cdot 036$ 
Citation: Al-Hindi B, Khaja A, Hanna SS, Alfeeli M, AlAwadh M, et al. (2020) The Use of Surgical Drains amongst the Orthopaedic Surgeons of Kuwait. J Surg Curr Trend Innov 4: 036.

Other important topics were not surveyed nor taken into account, such as prolonged antibiotics used, Venous Thromboembolism (VTE), and hospital acquired infection (non-wound related). This was due to different hospital policies which the authors could not standardize for the purpose of this study.

\section{Conflict of interest: None}

\section{Source of Support: None}

\section{References}

1. Memon MA, Memon MI, Donohue JH (2001) Abdominal drains: A brief historical review. Ir Med J 94: 164-166.

2. Ghaly DN, Khalifa YEM, Bakr HMA, Mahran MAA (2018) To use closed suction drain or not after total hip arthroplasty; A randomized controlled trial? J Curr Med Res Pract 3: 180-186.

3. Si HB, Yang TM, Zeng Y, Shen B (2016) No clear benefit or drawback to the use of closed drainage after primary total knee arthroplasty: A systematic review and meta-analysis. BMC Musculoskelet Disord 17: 183.

4. Armaghani SJ, Menge TJ, Lovejoy SA, Mencio GA, Martus JE (2014) Safety of topical vancomycin for pediatric spinal deformity: Nontoxic serum levels with supratherapeutic drain levels. Spine 39: 1683-1687.

5. Schroeder JE, Girardi FP, Sandhu H, Weinstein J, Cammisa FP, et al. (2015) The use of local vancomycin powder in degenerative spine surgery. Eur Spine J 25: 1029-1033.

6. Wang D, Xu J, Zeng WN, Zhou K, Xie TH, et al. (2016) Closed suction drainage is not associated with faster recovery after total knee arthroplasty: A prospective randomized controlled study of 80 patients. Orthop Surg 8: 226-233.

7. Boutsiadis A, Reynolds RJ, Saffarini M, Panisset JC (2017) Factors that influence blood loss and need for transfusion following total knee arthroplasty. Ann Transl Med 5: 418 .

8. Mujagic E, Zeindler J, Coslovsky M, Hoffmann H, Soysal SD, et al. (2019) The association of surgical drains with surgical site infections - A prospective observational study. The American Journal of Surgery 217: 17-23.

9. Kumar V, Singh A, Waliullah S, Kumar D (2019) Analysis of efficacy in postoperative use of closed suction drain in cases of traumatic dorsolumbar spine injury. J OrthopTraumatol Rehabil 11: 1-5.

10. VK Gautam, R Deshmukh, Kamra P, Gulati A, Banjare (2019) A prospective study to compare early postoperative outcomes in patients undergoing total knee replacement with or without drain. International Journal of Orthopaedics Sciences 5: 519-521.

11. Allegranzi B, Zayed B, Bischoff P, Kubilay NZ, de Jonge S, et al. (2016) New WHO recommendations on intraoperative and postoperative measures for surgical site infection prevention: an evidence-based global perspective. The Lancet Infectious Diseases 16: 288-303.
12. Ishida K, Tsumura N, Kitagawa A, Hamamura S, Fukuda K, et al. (2011) Intra-articular injection of tranexamic acid reduces not only blood loss but also knee joint swelling after total knee arthroplasty. Int Orthop 35: 16391645 .

13. Coskun D, Aytac J, Aydinli A, Bayer A (2005) Mortality rate, length of stay and extra cost of sternal surgical site infections following coronary artery bypass grafting in a private medical centre in Turkey. J Hosp Infect 60: 176-179.

14. Scomacao I, Cummins A, Roan E, Duraes EFR, Djohan R (2020) The use of surgical site drains in breast reconstruction: a systematic review. Journal of Plastic, Reconstructive \& Aesthetic Surgery 73: 651-662.

15. Parker MJ, Livingstone V, Clifton R, McKee A (2007) Closed suction surgical wound drainage after orthopaedic surgery. Cochrane Database Syst Rev 18.

16. Herrick DB, Tanenbaum JE, Mankarious M, Vallabh S, Fleischman E, et al. (2018) The relationship between surgical site drains and reoperation for wound-related complications following posterior cervical spine surgery: a multicenter retrospective study. Journal of Neurosurgery 29: 1-7.

17. Branch-Elliman W, O’Brien W, Strymish J, Itani K, Wyatt C, et al. (2019) Association of duration and type of surgical prophylaxis with antimicrobial-associated adverse events. JAMA Surgery 154: 590-598.

18. Barton A, Blitz M, Callahan D, Yakimets W, Adams D, et al. (2006) Early removal of postmastectomy drains is not beneficial: results from a halted randomized controlled trial. Am J Surg 191: 652-656.

19. Cobb JP (1990) Why use drains? J Bone Joint Surg Br 72: 993-995.

20. Liu Y, Li Y, Miao J (2016) Wound drains in posterior spinal surgery: a meta-analysis. J Orthop Surg Res 11: 16.

21. Chen ZY, Gao Y, Chen W, Li X, Zhang YZ (2014) Is wound drainage necessary in hip arthroplasty? A meta-analysis of randomized controlled trials. Eur J Orthop Surg Traumatol 24: 939-946.

22. Johansson T, Engquist M, Pettersson LG, Lisander B (2005) Blood loss after total hip replacement: a prospective randomized study between wound compression and drainage. Journal of Arthroplasty 20: 967-971.

23. Nixon J (2000) Wound drainage - the long term results after primary hip and knee arthroplasty [abstract]. Journal of Bone and Joint Surgery 2: 125.

24. Poeran J, Ippolito K, Brochin R, Zubizarreta N, Mazumdar M, et al.(2019) Utilization of Drains and Association With Outcomes: A Population-Based Study Using National Data on Knee Arthroplasties. J Am Acad Orthop Surg 27: 913-919.

25. Crowther CA, Harding JE (2007) Repeat Doses of Prenatal Corticosteroids for Women at Risk of Preterm Birth for Preventing Neonatal Respiratory Disease. Cochrane Database Syst Rev 18.

26. Mosleh S, Fard FB, Jokar M, Akbari L, Aarabi A (2019) Prevalence of Surgical Site Infection after Orthopedic Surgery and Some Related Factors at the Selected Hospitals of Isfahan University of Medical Sciences . Paramedical Sciences and Military Health 13: 43-53. 


\section{di \\ нетан}

Advances In Industrial Biotechnology | ISSN: 2639-5665

Advances In Microbiology Research | ISSN: 2689-694X

Archives Of Surgery And Surgical Education | ISSN: 2689-3126

Archives Of Urology

Archives Of Zoological Studies | ISSN: 2640-7779

Current Trends Medical And Biological Engineering

International Journal Of Case Reports And Therapeutic Studies | ISSN: 2689-310X

Journal Of Addiction \& Addictive Disorders | ISSN: 2578-7276

Journal Of Agronomy \& Agricultural Science | ISSN: 2689-8292

Journal Of AIDS Clinical Research \& STDs | ISSN: 2572-7370

Journal Of Alcoholism Drug Abuse \& Substance Dependence | ISSN: 2572-9594

Journal Of Allergy Disorders \& Therapy | ISSN: 2470-749X

Journal Of Alternative Complementary \& Integrative Medicine | ISSN: 2470-7562

Journal Of Alzheimers \& Neurodegenerative Diseases | ISSN: 2572-9608

Journal Of Anesthesia \& Clinical Care | ISSN: 2378-8879

Journal Of Angiology \& Vascular Surgery | ISSN: 2572-7397

Journal Of Animal Research \& Veterinary Science | ISSN: 2639-3751

Journal Of Aquaculture \& Fisheries | ISSN: 2576-5523

Journal Of Atmospheric \& Earth Sciences | ISSN: 2689-8780

Journal Of Biotech Research \& Biochemistry

Journal Of Brain \& Neuroscience Research

Journal Of Cancer Biology \& Treatment | ISSN: 2470-7546

Journal Of Cardiology Study \& Research | ISSN: 2640-768X

Journal Of Cell Biology \& Cell Metabolism | ISSN: 2381-1943

Journal Of Clinical Dermatology \& Therapy | ISSN: 2378-8771

Journal Of Clinical Immunology \& Immunotherapy | ISSN: 2378-8844

Journal Of Clinical Studies \& Medical Case Reports | ISSN: 2378-8801

Journal Of Community Medicine \& Public Health Care | ISSN: 2381-1978

Journal Of Cytology \& Tissue Biology | ISSN: 2378-9107

Journal Of Dairy Research \& Technology | ISSN: 2688-9315

Journal Of Dentistry Oral Health \& Cosmesis | ISSN: 2473-6783

Journal Of Diabetes \& Metabolic Disorders | ISSN: 2381-201X

Journal Of Emergency Medicine Trauma \& Surgical Care | ISSN: 2378-8798

Journal Of Environmental Science Current Research | ISSN: 2643-5020

Journal Of Food Science \& Nutrition | ISSN: 2470-1076

Journal Of Forensic Legal \& Investigative Sciences | ISSN: 2473-733X

Journal Of Gastroenterology \& Hepatology Research | ISSN: 2574-2566
Journal Of Genetics \& Genomic Sciences | ISSN: 2574-2485

Journal Of Gerontology \& Geriatric Medicine | ISSN: 2381-8662

Journal Of Hematology Blood Transfusion \& Disorders | ISSN: 2572-2999

Journal Of Hospice \& Palliative Medical Care

Journal Of Human Endocrinology | ISSN: 2572-9640

Journal Of Infectious \& Non Infectious Diseases | ISSN: 2381-8654

Journal Of Internal Medicine \& Primary Healthcare | ISSN: 2574-2493

Journal Of Light \& Laser Current Trends

Journal Of Medicine Study \& Research | ISSN: 2639-5657

Journal Of Modern Chemical Sciences

Journal Of Nanotechnology Nanomedicine \& Nanobiotechnology | ISSN: 2381-2044

Journal Of Neonatology \& Clinical Pediatrics | ISSN: 2378-878X

Journal Of Nephrology \& Renal Therapy | ISSN: 2473-7313

Journal Of Non Invasive Vascular Investigation | ISSN: 2572-7400

Journal Of Nuclear Medicine Radiology \& Radiation Therapy | ISSN: 2572-7419

Journal Of Obesity \& Weight Loss | ISSN: 2473-7372

Journal Of Ophthalmology \& Clinical Research | ISSN: 2378-8887

Journal Of Orthopedic Research \& Physiotherapy | ISSN: 2381-2052

Journal Of Otolaryngology Head \& Neck Surgery | ISSN: 2573-010X

Journal Of Pathology Clinical \& Medical Research

Journal Of Pharmacology Pharmaceutics \& Pharmacovigilance | ISSN: 2639-5649

Journal Of Physical Medicine Rehabilitation \& Disabilities | ISSN: 2381-8670

Journal Of Plant Science Current Research | ISSN: 2639-3743

Journal Of Practical \& Professional Nursing | ISSN: 2639-5681

Journal Of Protein Research \& Bioinformatics

Journal Of Psychiatry Depression \& Anxiety | ISSN: 2573-0150

Journal Of Pulmonary Medicine \& Respiratory Research | ISSN: 2573-0177

Journal Of Reproductive Medicine Gynaecology \& Obstetrics | ISSN: 2574-2574

Journal Of Stem Cells Research Development \& Therapy | ISSN: 2381-2060

Journal Of Surgery Current Trends \& Innovations | ISSN: 2578-7284

Journal Of Toxicology Current Research | ISSN: 2639-3735

Journal Of Translational Science And Research

Journal Of Vaccines Research \& Vaccination | ISSN: 2573-0193

Journal Of Virology \& Antivirals

Sports Medicine And Injury Care Journal | ISSN: 2689-8829

Trends In Anatomy \& Physiology | ISSN: 2640-7752

Submit Your Manuscript: https://www.heraldopenaccess.us/submit-manuscript 